\title{
PROFESSIONAL DEVELOPMENT OF ACADEMIC STAFF IN SWEDEN ON EXAMPLE OF RESEARCH UNIVERSITY
}

\begin{abstract}
The article deals with the professional development of teaching staff in Sweden on the example of Lund Research University. The author reveals the national strategy for the development and support of higher education staff in Sweden, as well as the features of the educational activities of Swedish higher education teachers on the example of Lund University. The author reveals the university's approach to improving the activities of teachers, namely the introduction of a teaching course in higher education is mandatory for all who teach at Lund University. We are talking about the course "Teaching and learning in higher education" or "Development of a course in higher education". Accordingly, teachers who supervise doctoral students must undergo special teacher training.

Keywords: research university, teaching staff, teacher's training.
\end{abstract}

Introduction. Modern system of professional pedagogical training in universities is quite dynamic and requires flexibility, adaptability, consistency and strategic character from the education sector. It is trained pedagogical staff that ensures the progressive renewal of the teaching staff and growth of human capital in any country. The results of teaching staff development and the state of realization of their professional potential depend on the quality of training of teaching staff. In the context of formation of the directions of Ukraine's European integration, the implementation of the world experience of professional training of pedagogical personnel is relevant, and within Europe, the system of training teachers in Sweden demonstrates one of the leading practices.

Analysis of recent research and publications. This topic was studied by a significant number of both foreign and domestic scientists and practitioners, including: A.A. Marushkevych, N.V. Koshechko, B.V. Avramenko, G. Bilyanin, G. Velikanova, V.A. Gladush, Yu.E. Demidova, A.E. Tveritnikova, N. Iliash, A.V. Zhabenko, T.G. Zharovtsev, N.A. Kirichenko, A.L. Klimenko, N.I. Klokar, A.V. Kovtun, I.S. Kocharyan, A.M. Bezus, Yu. Kuzmenko, A.A. Listopad, V.V. Oleinik, I. Oros, G.P. Polyakova and others.

Presentation of the main positions. Higher Education Institutions in Sweeden used to appoint their own teaching staff. Teachers at state universities and university colleges may be appointed as professors, lecturers, assistant lecturers, post-doctoral fellows, part-time teachers and guest lecturers (including visiting professors, lecturers and assistant lecturers). Apart from the employment of professors and lecturers which is regulated by the Higher Education Act (Högskolelagen). The university or university college decide to what extent a position should focus on education, research (or development work in the arts for staff in the art field) and administration. Teaching staff from all categories has teaching duties in undergraduate education, however, post-doctoral fellows mainly carry out research.

Promotion of teaching staff in the higher education sector is regulated in the Higher Education Ordinance. A senior lecturer permanently employed at a state higher education institution shall on application be promoted to a permanent position as a professor at the institution, if the senior lecturer is qualified for such a position. Corresponding rules apply for promotion from a position as junior lecturer to senior lecturer. Teaching skills are emphasised in the qualification requirements for all categories of teachers [Eurydice, 2018].

Continuing professional development of academic staff has been expressed in the Higher Education Act as a general obligation for the teacher without concrete quantification. The higher education institutions and staff have a high level of autonomy in the organisation and participation in CPD. Incentives for Participation in Continuing Professional Development (CPD) Activities. Higher education institutions have full autonomy regarding incentives for individual Continuing Professional Development (CPD). There are several national programmes that offer funding for international CPD for academic staff.

Lund University was founded in 1666 and is ranked among the world's top 100 universities. The University has 40000 students and 8160 staff based in Lund, Helsingborg and Malmö - the 4th most inventive city in the world by Forbes in 2013. Lund University is highly ranked in many international comparisons of higher education institutions and has been consistently placed in the world's top 100 universities in recent years (among the top $0.4 \%$ of the world's universities); the highest ranked university in Sweden in the QS Rankings 2021. It is also consistently ranked among the world's top 100 universities in world university rankings. Lund University is ranked in the top 150 and 200 in the THE and ARWU rankings, respectively [Lund University, 2020].

According to internationalization Lund University has a lot of achievements, for example position 40th in the Times Higher Education (THE) Most International Universities in the World Rankings 2021; or The Most International Universities in the World Rankings 2021 [Priority areas..., 2017].

Mentioned in strategic plan 2017-2026 of Lund university that Education and research are to be intertwined. Teaching methods, course content and the students' own learning process are to equip students and doctoral students to meet new challenges. The teaching staff shall be highly qualified in teaching and learning and increased educational quality shall be particularly rewarded [Priority areas..., 2017].

The courses for teaching in higher education are mandatory for everyone who teaches at Lund University. Courses are offered by the Division for Higher Education Development as well as the faculties. Lund University's employment act requires at least five weeks of course work for academic positions. This requirement is met by taking "Teaching and learning in higher education" or "Course design in higher education" course. Doctoral students who teach are required to take at least the first of these two courses. Teachers, who supervise students in doctoral education, must have undergone special supervisor training. The courses offered by the Division for Higher Education Development (AHU) are paid for by the Faculty of Social Sciences if you are admitted to the course and employed at the faculty.

The learning environment and teaching style which potential teaching staff should learn how to provide open environment. Students experience an open, informal study 
environment with teachers and students usually on a firstname basis. The traditional academic hierarchy is replaced by a more collaborative approach, where students are respected as junior colleagues and their opinions valued and encouraged by more experienced peers. This approach encourages dialogue and collaboration between students and teachers and creates opportunities to bring forward new ideas and innovations. Student-centred education - there is a lot of support in terms of pedagogy and the teachers make themselves available to help students and ensure course content is fully understood. There is a focus on enabling students to develop their critical and analytical thinking skills, independent research skills, group work, problem solving and leadership skills so as to prepare them for their career. Research university level academic staff should be able to provide International class. Lund University is proud to have a strong international profile - they attract students from almost 150 countries. This creates global classroom environments where students encounter different cultural perspectives and start to build their international network. Studies at Lund University are usually undertaken one course (unit/module) at a time, with an examination or essay at the end of each individual course. Studies at the Faculty of Engineering are an exception in that two or more courses are often studied in parallel. Courses can be from two to 20 weeks long, with five, 10 and 20 weeks being the most common lengths [Lund University, 2020].

Teaching stuff should be trained to provide lectures, as the most common form of instruction, to groups of 25-30 students. Students are also expected to work independently and develop an in-depth knowledge of their subject through independent study, which is a large part of the learning process takes place outside the classroom as students read and discuss the course material with each other. Students at Lund University are trained to efficiently assess large amounts of information. Study techniques are taught in the classroom and also by study advisors and through workshops, which future teaching staff should be prepared to organize. Group work is common for many of our degree programmes. The goal is for students to practise teamwork in small groups, across different cultures within the class, and also to develop problem solving and leadership skills. Group work is an important aspect to the learning experience in order to simulate the real dynamics of an international work place.

For providing mentioned above learning process future teaching stuff should be treained to implement different teaching methods used to focus on the critical analysis of the course content with the use of real case studies wherever possible. International guest lecturers and speakers from business, government, NGOs and research regularly feature as part of the curriculum to further connect studies to the professional world [Lund University, 2020].

Education at Lund University is closely aligned to current research, often drawing on the interdisciplinary research approach that has helped secure Lund University's place as Sweden's strongest research university. Lund University educates some 40000 students per year, and close to $60 \%$ of the University's budget goes to research, illustrating our commitment to being one of the world's top researchintensive universities. This should be taken into account while academic staff training, so they can work in the same direction. Such as Ukrainian universities are still working on building world class research university they should take this important note into account and provide their teaching stuff preparation in similar direction, so they can more intensively implement scientific approach into educational process.
Critical thinking and freedom of mind are the cornerstones of academic life at Lund University. By critical thinking teaching staff of Lund University mean the ability to assess information on different topics and to form independent and well informed opinions; to scrutinise and question beliefs that are sometimes taken for granted; to revise opinions in the light of new evidence or knowledge; and to give and receive criticism in a constructive and generous manner, as well as the readiness to engage in discussion with fellow students and to learn from others.

By freedom of mind staff of Lund University mean the ability to liberate oneself from narrow-minded and conventional wisdoms, to value the authenticity of ideas and experiences in whatever shape they may come, and to appreciate and seek fresh perspectives on old ideas; in short, the ability to think 'outside the box'. Critical thinking and freedom of mind are stimulated in all activities at the University. In seminars, workshops and experiments, students analyse and present solutions to given problems and assignments. Theoretical concepts are tested in practical situations, and practical experiences are employed to develop and enrich theory [The learning environment.., 2021].

Although the above-mentioned initiatives have made a significant contribution, we still need to learn a great deal about how to support the introduction of innovative researchbased approaches to teaching. Not only is this type of work often seen as peripheral to educational research issues, but it is also very costly in terms of time and material costs of large-scale implementation projects, let alone study their impact. In addition, there are currently several generally accepted approaches to project design and evaluation that focus on the large-scale implementation of innovative teaching practices.

Conclusion. The analysis of the use of the Swedish experience in the process of professional training of teachers in the educational realities of Ukraine indicates the possibility of adapting the leading pedagogical experience in the context of training and lifelong training of teachers. At the same time, important forms of professional training of teachers based on Swedish experience should be master classes, open lectures, distance learning, group work, intensification of independent learning. Several countries have introduced or are planning to introduce mandatory teacher education initiatives for teachers in higher education institutions, drawing on the experience of Sweden.

Research on the consequences and effectiveness of pedagogical training in higher education institutions is growing. Pedagogical training courses can contribute to changes in participants' approaches to teaching and learning, as well as their learning practices. Pedagogical training can improve participants' attitudes to teaching, as students value the training of teachers who have been trained more than teachers who have not, and that students who receive guidance from teachers who have participated in teaching learn more effectively.

References

Eurydice https://eacea.ec.europa.eu/national-policies/eurydice/content/ continuing-professional-development-academic-staff-working-highereducation-73_en

Lund University, Teaching education programe https://www.uvet.lu.se/en/ education/teacher-education-programme

Priority areas 2017-2026 LUND univer Strategic Plan 2017-2026 | LUND UNIVERSITY [https://www.lunduniversity.lu.se/sites/www.lunduniversity.lu.se/ files/strategic_plan_2017-2026-updated030517.pdf].

The learning environment and teaching style https://www.lunduniversity.lu.se/admissions/study-lund-university/learning-environment-and-teaching-style

Надійшла до редколегії 28.05.21 
Ілона Маріуц, канд. пед. наук, асист.

ORCID iD: 0000-0001-5032-2014

Вероніка Бовсуновська, студ. магістратури

Київський національний університет імені Тараса Шевченка, Київ, Україна

\section{ПРОФЕСІЙНИЙ РОЗВИТОК АКАДЕМІЧНОГО ПЕРСОНАЛУ У ШВЕЦІЇ НА ПРИКЛАДІ ДОСЛІДНИЦЬКОГО УНІВЕРСИТЕТУ}

Розглянуто професійний розвиток викладацького складу в Швеції на прикладі дослідницького університету Лунд. Досліджено загальнодержавну стратегію розвитку і підтримки викладачів вищої школи у Швеції, а також особливості навчальної діяльності на прикладі університету Лунд. Розглянуто підхід університету до вдосконалення діяльності викладачів, а саме: запровадження курсу викладання у вищій школі обов'язкове для всіх, хто викладає в університеті Лунда. Йдеться про проходження курсу "Викладання та навчання у вищій освіті" або "Розробка курсу у вищій освіті". Відповідно, викладачі, які контролюють студентів у докторантурі, повинні пройти спеціальну підготовку керівника. Вищі навчальні заклади Швеції самостійно призначають викладачів на посади. Зайнятість професорів і викладачів регулюється Законом про вищу освіту - Högskolelagen. Університет або університетський коледж вирішує, якою мірою посада має бути зосереджена на освіті, наукових дослідженнях та адмініструванні. Викладацький склад усіх категорій виконує обов'язки викладачів, докторанти в основному проводять дослідження. У стратегічному плані університету Лунда на 2017-2026 роки вказано, що освіта і дослідження мають бути взаємопов'язаними. Методи викладання, зміст курсу і власний процес навчання студентів спрямовані на підготовку студентів та докторантів до нових викликів. Педагогічний колектив має бути висококваліфікованим у навчанні, а підвищена якість освіти має бути особливо винагороджена.Навчальне середовище і стиль викладання, який потенційний викладач повинен навчитися забезпечувати, - це відкрите середовище. Студенти відчувають відкрите, неформальне навчальне середовище з викладачами та студентами. Традиційну академічну ієрархію замінює більш спільний підхід, коли студентів поважають як молодших колее, а їхні думки цінують і заохочують більш досвідчені колеги. Цей підхід стимулює діалог і співпрацю між студентами та викладачами і створює можливості для висування нових ідей та інновацій. Освіта орієнтована на студентів, і тому вчителі істотно допомагають їм та забезпечують повне розуміння змісту курсу. Основну увагу приділено тому, щоб дати студентам змогу розвивати навички критичного й аналітичного мислення, незалежних досліджень, групової роботи для вирішення проблем і лідерські якості, щоб підготувати їх до майбутньої кар'єри. Науково-дослідний персонал Університету повинен відповідати міжнародному рівню. Університет Лунда пишається тим, що має сильний міжнародний профіль - він залучає студентів із майже 150 країн. Це створює глобальне середовище є класі, де студенти стикаються з різними культурними перспективами і починають будувати свою міжнародну мережу.

Ключові слова: дослідницький університет, викладацький склад, підготовка викладачів. 